\title{
FORMULATION OF A RATIONAL FERTILISER PROGRAMME IN TUSSOCK COUNTRY
}

T. E. LUDECKE, Scientific Officer, Department of Agriculture, Alexandra.

New Zealand agriculture is primarily dependent on the growth of high-producing pastures which rely on legumes for their nitrogen supply. Legumes under favourable conditions are able to. fix large amounts of nitrogen through nodule bacteria attached to their roots. Nitrogen is supplied to grasses by underground transference after the needs of the host plant are satisfied, and is also provided from the urine and dung of grazing animals. Almost invariably, poor pasture growth in New Zealand is the result of low legume production. Contributing factors to this are a poor supply of available phosphorus, sulphur, molybdenum, and potassium, ineffective nodulation, and acid soil conditions.

Many workers (Walker, Adams, and Orchiston (1955) and Lobb and Bennetts (I 958) ) have shown that the key to improving the lowland native tussock grasslands of the South Island is also to establish and maintain good legume growth. In these grasslands the main nutrient deficiencies which limit the growth of legumes are sulphur, phosphorus, and molybdenum. Sulphur deficiencies are widespread, probably because of low atmospheric returns.

The purpose of this paper is to set out the methods by which were determined the kinds and quantities of fertiliscr required by the different soils in the tussock grassland regions of Central Otago to obtain satisfactory legume establishment and growth. This involved selecting soils classed as a sequence according to the New Zealand genetic system of classification; carrying out field trials; measuring the responses to sulphur and phosphorus, and correlating these responses with soil chemical data (Ludecke (1962) ). The same principles as used in Central Otago will apply to formulating fertiliser programmes for other soil sequences in tussock grassland areas. The economic significance of these results will also be discussed.

The aim of tussock country improvement in Central Otago is two-fold. Firstly, to improve pastoral production both by increasing stock performance (i.e., increasing wool weights and lambing percentages, decreasing death rates, rearing fat lambs) and increasing sheep and cattle numbers; secondly, to improve the lower country so that the grazing pressure can be eased on the higher snowgrass country, where soil and water conservation is vital for irrigation and hydro-electric schemes, Over the last five to IO years, control of rabbits and development of aerial topdressing and oversowing have enabled farmers to take advantage of research findings on tussock grassland improvement. 


\section{Soils of the Tussock Grassland Regions of Central Otago}

The soils of the tussock grasslands of Central Otago are derived from mica-schist and are zonal soils according to the genetic classification of New Zealand soils (Taylor and Pohlen (1959) ), but a large number are steepland soils related to zonal soils. Zonal soils are subdivided into various groups according to the climate and vegetation. When the soils are classified in this manner a simple pattern emerges.

In the genetic classification of New Zealand soils the five soilforming factors are reduced to three effective variables: these arc parent material, weathering stage, and degree of leaching. The arrangement of soils from similar parent materials in order of weathering and leaching (soil suites) has been widely used by New Zealand soil scientists.

Central Otago soils are weakly weathered, but they vary in their degree of leaching according to precipitation. There is a wide range of climate and vegetation, and hence there is a wide range of zonal soils. This range extends from brown-grcy earths through yellow-grey earths, southern yellow-brown earths and related podzolised soils, and upland yellow-brown earths to high country yellow-brown earths and related podzolised soils. Eleven sites were selected, representing the main groups of zonal soils. The rainfall, vegetation, soil, and zonal soil group at each one of these sites is shown in Table 1 . The location of these trial sites is shown in Fig. I.

TABLE I

\begin{tabular}{|c|c|c|c|}
\hline Trial Site & $\begin{array}{l}\text { Rainfall } \\
\text { in. }\end{array}$ & Vegetation & $\begin{array}{l}\text { Soil and Zonal } \\
\text { Soil Group }\end{array}$ \\
\hline 1. Moutere & 16 & Depleted fescue & Pigburn, B.G.E. \\
\hline 2. Waitiri & 20 & Rejuvenated fescue & Arrow, Y.G.E.":' \\
\hline 3. Bendigo $(2,500$ & & & \\
\hline $\mathrm{ft}$ ) & 22 & Depleted fescue & Blackstone, Y .G.E. \\
\hline 4. Crown Terrace & 23 & Fescue association & $\begin{array}{l}\text { Crown Terrace, } \\
\text { Y.G.E. }\end{array}$ \\
\hline 5. Lagoon Valley & 24 & Rejuvenated fescue & Arrow, Y.G.E."' \\
\hline 6. Mt Benger & 28 & Fescue association & Blackstone, Y.G.E. \\
\hline 7. Glendhu & 32 & Fescue association & $\begin{array}{l}\text { Bourke, Southern } \\
\text { Y.B.E. }\end{array}$ \\
\hline 8. Glendhu & 33 & Fescuc association & $\begin{array}{l}\text { Bourke, Southern } \\
\text { Y.B.E. }\end{array}$ \\
\hline 9. Bridge Huts & 35 & $\begin{array}{l}\text { Snow tussock } \\
\text { association }\end{array}$ & $\begin{array}{l}\text { Wehenga, Upland } \\
\text { Y.B.E. }\end{array}$ \\
\hline 10. Crown Range & 38 & $\begin{array}{l}\text { Snow tussock } \\
\text { association }\end{array}$ & $\begin{array}{l}\text { Dunstan, High } \\
\text { Country Y.B.E.* }\end{array}$ \\
\hline 11. Hunter Valley & 40 & $\begin{array}{l}\text { Bracken fern } \\
\text { association }\end{array}$ & $\begin{array}{l}\text { Moonlight, Podzol- } \\
\text { ised Southern } \\
\text { Y.B.E." }\end{array}$ \\
\hline
\end{tabular}

*Steepland soils associated with the zonal group. 


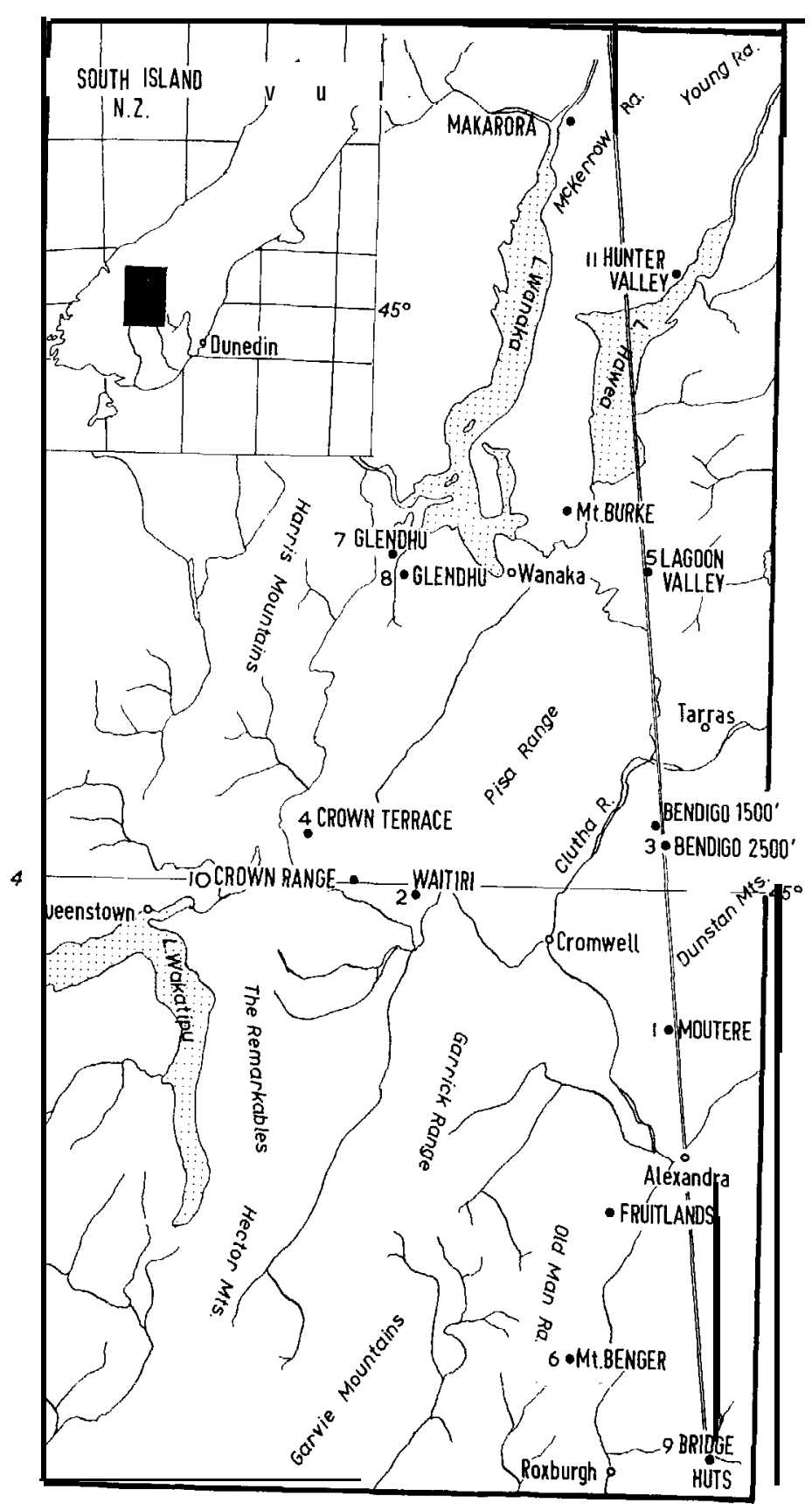

Fig. I-Trial sites. 
Brown-grey earths: These soils have developed under annual rainfalls of less than $17 \mathrm{in}$. and are dry most of the year. The mean temperatures arc cool with a wide diurnal and annual range. The original vegetation was a fescue, silver, and blue tussock association. This vegetation was depleted over much of the region owing to fire and overgrazing by rabbits and sheep. It was replaced by scabweed and small annual and perennial grasses. These soils are capable of considerable improvement by the introduction of dryland lucerne pastures by two methods, the conventional method of land development (Lunn (1955), Schofield (1957) ) or direct surface introduction (Ludecke (1962a) ). Since the rabbit has been brought under control the vegetation of these soils can be improved by allowing natural regeneration to take place (Hercus 1961) ).

Yellow-grey earths: These soils occur under an annual precipitation of 20-35 in. and are dry in summer. The mean temperatures are cool with a moderate to wide annual range. The vegetation is fescue tussock associations. These soils occur extensively on the mountain ranges at an altitude of 1,500 to $3,000 \mathrm{ft}$ and arc capable of considerable improvement by aerial oversowing with clovers and topdressing with sulphurised superphosphate (Ludecke (1960) ). The soils at Sites 2-6 inclusive fall into this group.

Y ellow-brown Earths: Soils of this group occur in regions where the rainfall is adequate for plant growth and the soils are damp and seldom dry out. The yellow-brown earths in Central Otago can be divided into four sub-groups:

1. Southern yellow-brown earths occur extensively in the Lakes district of Central Otago up to an altitude of 3,000 ft. These soils have been shown to bc capable of considerable improvement by aerial topdressing and oversowing (Ludecke (1960) ). The soil at Sites 7 and 8 are representative of this sub-group.

2. Upland yellow-brown earths occur on the upland plateau in Otago west of Dunedin, and stretch as far west as the Pinelheughs, near Roxburgh. North and south they extend from Macraes Flat to Lawrence. The vegetation is snowgrass. The soil from Site 9 falls into this group. These soils can also be improved markedly by aerial oversowing and topdressing (Ludccke (1960)).

3. High country yellow-brown earths lie around the perimeter of the semi-arid basins and intcrmontanc valleys of the Clutha River and Taieri River catchments. Soil and water 
conservation in these catchments is vital for hydro-electric and irrigation schemes and for the prevention of flooding in lowland districts. The soil at Site 10 is representative of this group.

4. Podzolised southern yellow-brown earths and podzolised high country yellow-brown earths occur in the higher rainfall districts to the west of the Otago lakes. There is no sharp boundary between yellow-brown earths of sub-groups 1 and 3 and these soils, but rather a wide transition zone of up to 20 miles (McCraw ( 1957) ). The soil at Site 11 falls into this transition zone. These soils, where the vegetation is bracken fern associations, have been shown to be capable of considerable improvement (Ludecke ( 1960) )

\section{Field Trials}

In trials laid down at Sites 1, 2, 8, and 9 in the 1958 and 1959 seasons Ludecke (1960) found that all these soils were sulphur deficient. No responses were obtained to phosphate alone, and the responses to phosphate in the presence of sulphur varied from nil at Site 1, where the soil is a brown-grey earth, to marked responses at Site 9, where the soil is an upland yellow-brown earth.

\section{MOUTERE TRIAL * PIGBURN SOIL B.GE}

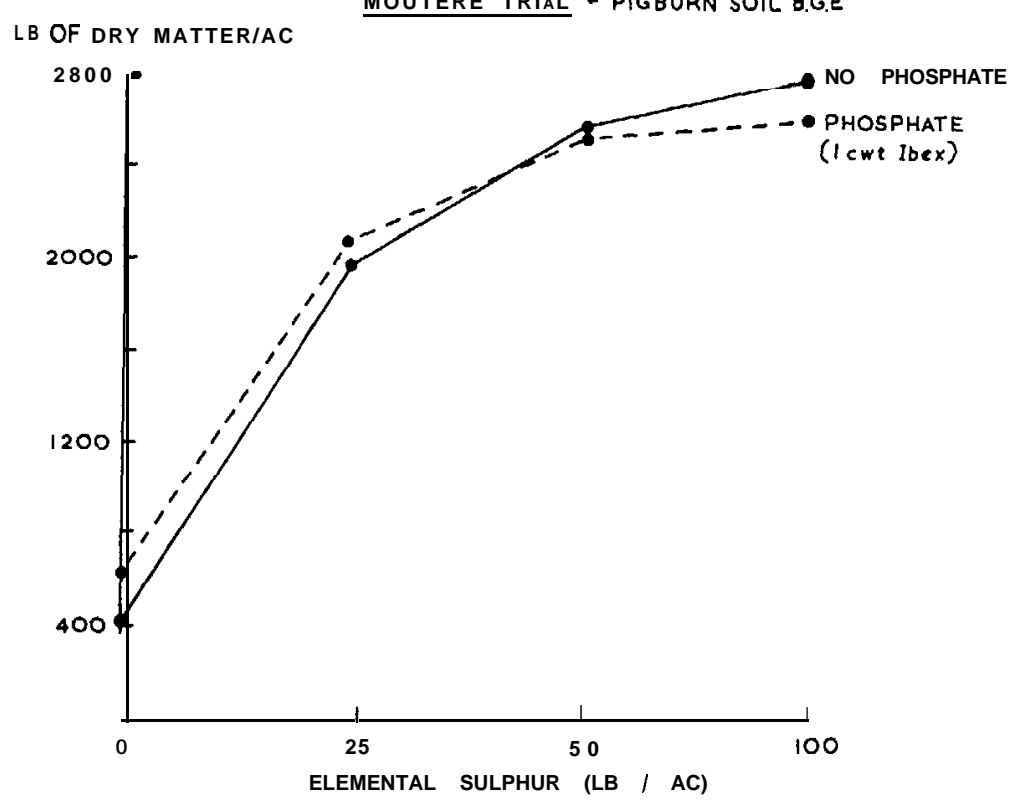

Fig. 2 
In the spring of 1960 rates of sulphur by rates of phosphate trials were laid down to establish the type and optimum rate of fertiliser required to give maximum establishment and growth of legumes on the different soils. The response indicator plants in all these trials were clovers (white, red, and alsike) except at Site 1, where lucerne was used. The responses were measured by fertility index pointings only (Lynch and Mountier (1959) ) except at Site 1, where dry-matter production cuts were obtained. At Site 1 good agreement has been obtained between fertility index pointings and actual dry-matter production. The sulphur and phosphorus responses for each trial were calculated from fertility index pointings made 15-18 months after laying down of the trials.

This series of trials again showed that the main factor limiting the growth of legumes in Central Otago was an acute and widespread sulphur deficiency. Approximately $50 \mathrm{lb}$ of elemental sulphur was required to obtain maximum legume establishment and growth. At all sites except Site 11 there were marked responses to sulphur alone. At Site 11 there were depressions in the growth of clover with heavier sulphur dressings (Fig. 4). This was possibly owing to the soil at this site having a high exchangeable manganese content (Walker, Adams, and Orchiston (1955a)).

No phosphate responses were obtained on any soils until the sulphur deficiency had been satisfied. The responses to phosphate in the presence of sulphur varied widely. At Site I on the browngrey earth no responses were obtained to phosphate in the presence of sulphur (Fig. 2); with increasing leaching the responses to phosphate in the presence of sulphur increased (Fig. 3) until at Site 11, on the southern podzolised yellow-brown earth, very marked responses were obtained (Fig. 4).

Molybdenum was found to limit the growth of legumes at Sites 9 and I 1 only.

By obtaining the optimum treatment from each trial and knowing the purity of the experimental materials (the sulphur and phosphorus contents of superphosphate and sulphur-enriched superphosphate) a recommendation can be made to farmers on the different groups of zonal soils as to the type and quantity of fertiliser they should use to obtain maximum legume establishment and growth. These results are of great practical significance to the farming community. For example, at Site 4 (yellow-grey earth soil) it was found that $50 \mathrm{lb}$ of sulphur with $14 \mathrm{lb}$ of phosphorus as calcium mono-phosphate per acre were required to obtain maximum legume production. To apply this amount of sulphur and phosphate the farmer would need to apply either approximately: 


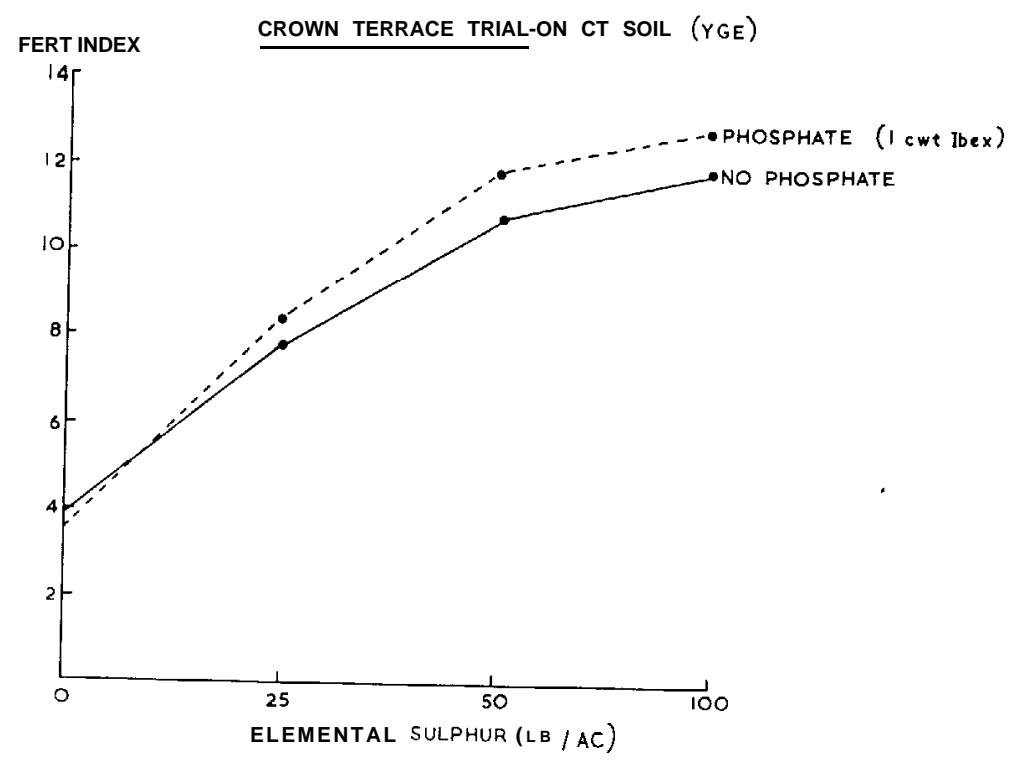

Fig. 3

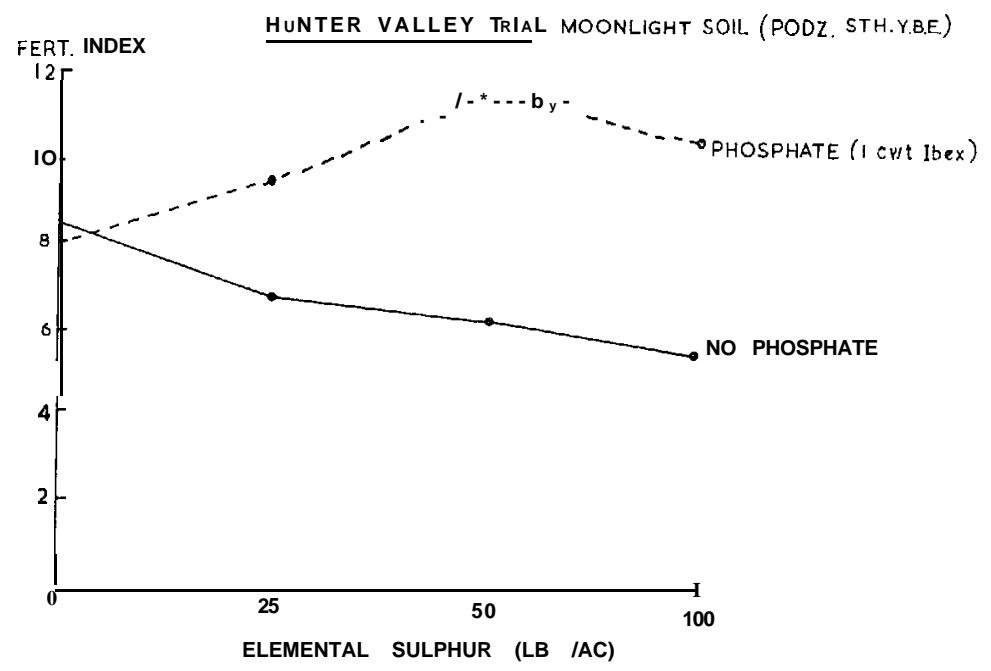

Fig. 4 
(L) $4 \mathrm{cwt}$ of superphosphate.

(2) $2.2 \mathrm{cwt}$ of sulphurised superphosphate (200 lb mixture).

(3) $1.7 \mathrm{cwt}$ of sulphurised superphosphate (400 lb mixture).

By using the latter sulphur-enriched fertiliser, the farmer is saving a great deal of expense in cost of fertiliser, transport costs, and application costs.

\section{Soil Chemistry Studies}

The soils at each site were sampled by horizons on a volumeweight basis so that the weight of soil per acre-inch for each horizon could be determined, and consequently the weights of different elements.

With increasing leaching there was a marked fall in the $\mathrm{pH}$ of the soils from 6.2 in the topsoil at Site 1 to 5.0 in the topsoil at Site 11 .

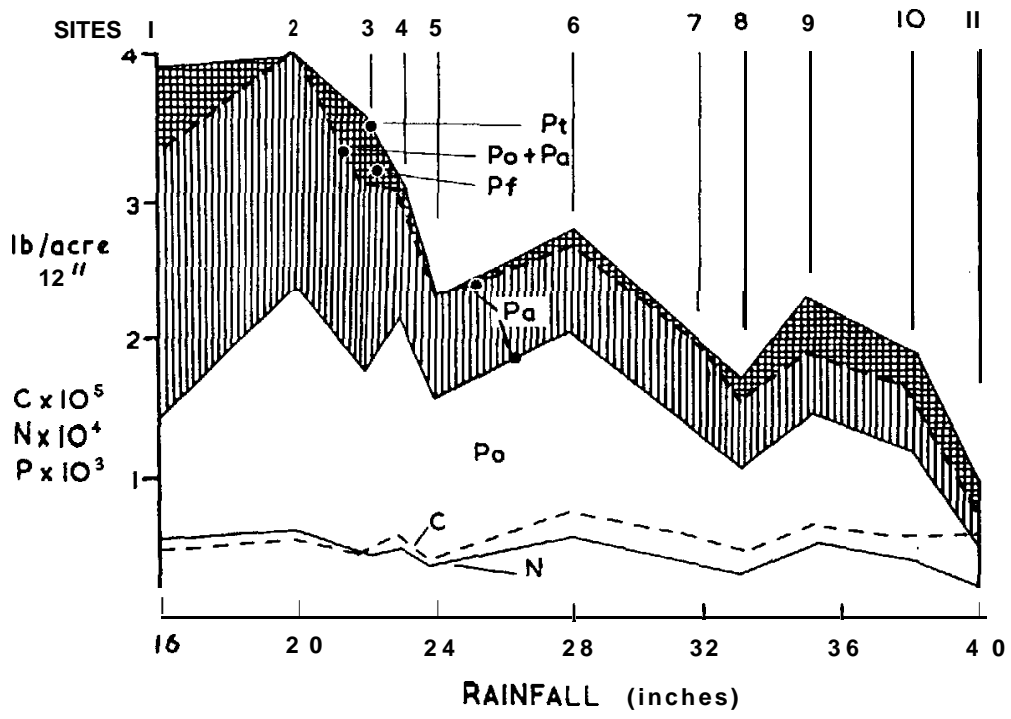

Fig. 5

Fig. 5 shows the pounds of carbon and nitrogen per acre for each site to a 12 in. depth. It also shows that the carbon : nitrogen ratio increases with increasing leaching, being less than 10 for the brown-grey earth and increasing to 23 for the southern podzolised yellow-brown earth.

The nitrogen : sulphur ratios were found to be remarkably similar, both between soils at the different sites and between horizons of the same soil. This suggests that most of the sulphur in these soils is in organic form. Walker and Adams (1958) 
showed that grasses will utilise 95 per cent or more of the sulphur made available from the mineralisation of organic matter. Thus legumes depend almost entirely on sources of sulphur other than the soil. The widespread and acute sulphur deficiencies in Central Otago are due to low atmospheric returns of sulphur.

In Fig. 5 the effect of increased leaching on the pounds per acre of different forms of soil phosphorus to a depth of 12 in. is shown. The symbols used to denote the different forms of soil phosphorus are:

$\mathrm{P}$, = Total $\mathrm{P}$ by the HF-HNO method of Metson (1956) and Saunders ( 1957).

$\mathrm{P}_{4}+\mathrm{P}_{\mathrm{a}}=$ Total $\mathrm{P}$ by the $\mathrm{H}_{2} \mathrm{SO}_{4}$ method of Saunders and Williams (1955) and Walker and Adams (1958a).

$\mathrm{P},=$ Organic $\mathrm{P}$.

$\mathrm{P}_{\mathrm{:}:}=$ Inorganic $\mathrm{P}$ soluble in $\mathrm{N} \mathrm{H}_{2} \mathrm{SO}_{4}$.

$\mathrm{P}_{\mathrm{f}}=$ Inorganic $\mathrm{P}$ insoluble in $\mathrm{N} \mathrm{H}_{2} \mathrm{SO}_{4}$.

With increasing leaching (rainfall) the amount of total phosphorus declines and organic phosphorus becomes a greater percentage of the total soil phosphorus. A very similar pattern of results was obtained by Walker and Adams (1959) when working on weakly weathered greywacke soils in the Mackenzie Country.

In the A horizon of the soil at Site 1 there was found to be over $300 \mathrm{lb}$ per acre-inch of total phosphorus, whereas in the A horizon of the soil at Site I 1 there was less than $100 \mathrm{lb}$ per acreinch, In the A horizon of the brown-grey earth there was $210 \mathrm{lb}$ per acre-inch of inorganic phosphorus, and the percentage organic phosphorus of the total was 35 per cent. This is to be compared with the A horizon of the southern podzolised yellow-brown earth, where there was only $9 \mathrm{lb}$ per acre-inch of inorganic phosphorus and the percentage organic phosphorus of the total increased to 90 per cent.

As is shown in Fig. 5 in the weakly leached brown-grey earth at Site I, the amount of inorganic phosphorus insoluble in $\mathrm{N} \mathrm{H}_{2} \mathrm{SO}_{4}\left(\mathrm{P}_{\mathrm{f}}\right)$ is a very small percentage of the total inorganic phosphorus. In the strongly leached soils of the sequence $P_{i}$ is a large percentage of the total inorganic phosphorus. This result is in agreement with the findings of Wells and Saunders (1960), who considered that the major cause of the decreasing levels of available phosphorus with weathering and leaching was the change in the nature of the inorganic phosphorus.

Thus, as the amount of inorganic phosphorus available for legume growth declines with increasing leaching the response to phosphate fertilisers in the presence of sulphur increases.

Separate O-3 in. samples were taken from each site and the available phosphate status was determined by the Department 
of Agriculture's Truog phosphate quick test. It was found that the Truog test gave a reasonable indication of the total inorganic phosphate status of the soil to a 3 in. depth (Fig. 6).

TRUOG $P$

$0-3^{\prime \prime}$

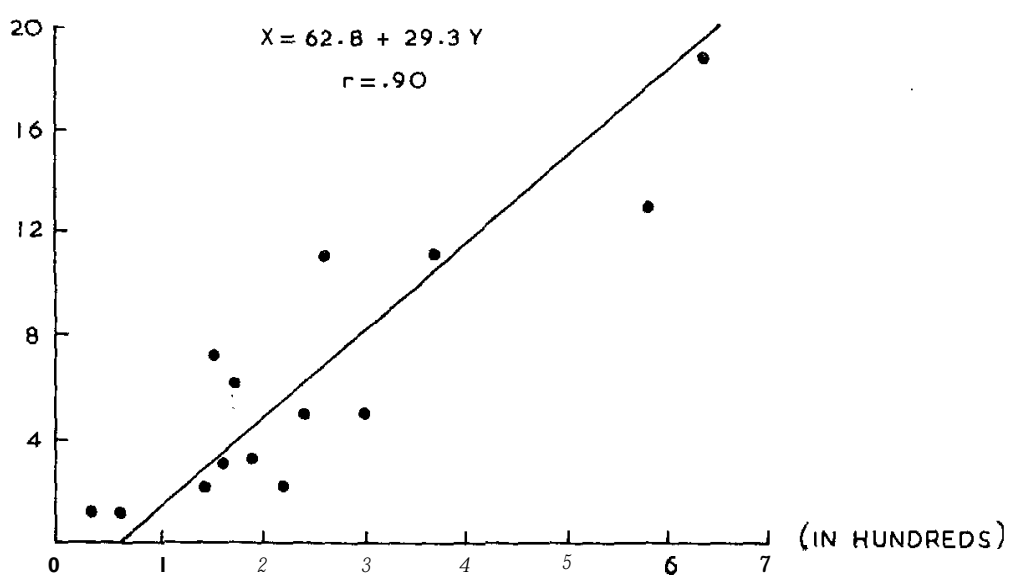

l B INORganic Phosphate / AC PROFIle 3 " DEPTH

Fig. 6

A very close relationship (Fig. 7) was found between the Truog phosphate status of the soil and the percentage response to phosphate in the presence of sulphur as found in the field trials.

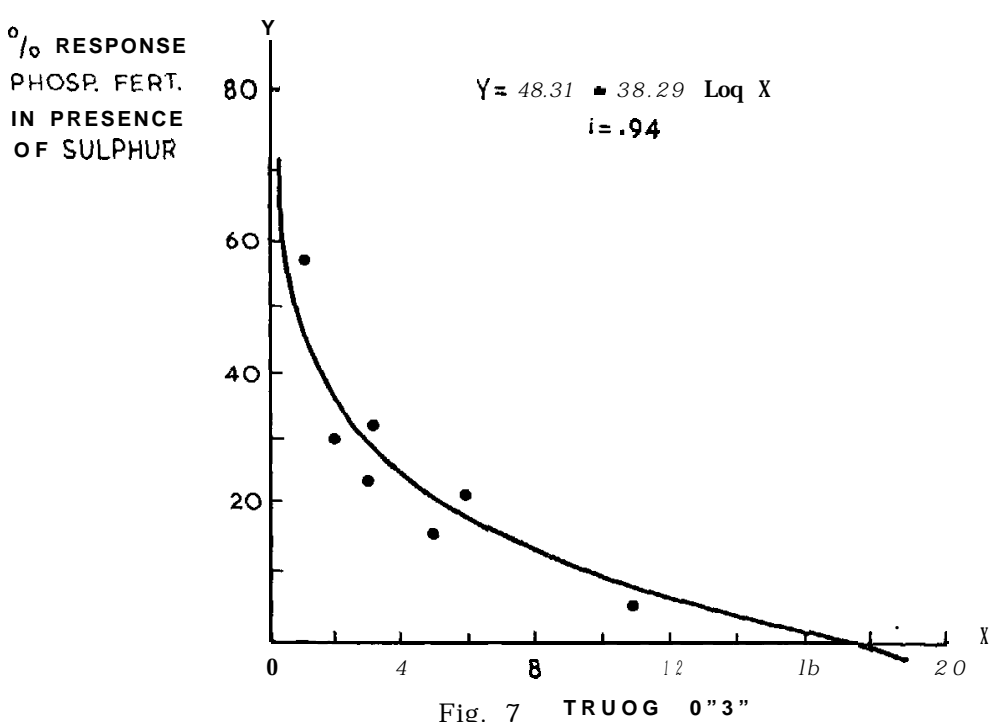




\section{Conclusion}

From these results sound topdressing advice can be given to dry-land farmers in Central Otago. The likely response to phosphate fertilisers in the presence of sulphur can be obtained by taking a O-3 in. soil sample and obtaining the Truog phosphate value of the soil. Also the inorganic phosphate status of the soil can be assessed. The rates of sulphur by rates of phosphate trials give the amount of phosphate fertiliser required to correct a given deficiency; and as all soils are known to be sulphur deficient to the same degree, a sound recommendation can be made to the farmer as to the type and quantity of sulphurised superphosphate which should be applied to obtain maximum legume establishment and growth.

The results of this study emphasise the importance of using soil sequences as a basis for soil-fertility investigations.

\section{Acknowledgements}

I would like to express my gratitude to the following people who have assisted me in this work: Professor T. W. Walker, Lincoln College; $\mathrm{Mr}$ J. D. McCraw, Soil Bureau, Alexandra; my colleagues in the Department of Agriculture, particularly, Mr J.R. Bruce-Smith, and the farmers of Central Otago on whose properties the field trials have been carried out.

\section{R eferences}

Hercus, J. M . ( 196 I ): Tussock Grassland Improvement by Grazing Management. N.Z.J.A., 103:257-261.

Lobb, W. K. and Bennetts, R. L. (1958): Improvement of Tussock Grassland in Canterbury. Ibid, 96:537-549.

Ludecke, T. E. (1960): lmprovement of Low Altitude Tussock Country in Central Otago. Proc, 22nd Conf. N.Z. Grassl. Assn.: 96-1 10.

Ludecke, T. E. (1962): The Soil Chemistry of Some Central Otago Soils in Relation to the Pattern of Field Responses to Sulphur and Phosphorus. M.Agr.Sc. Thesis Lincoln College Library.

Ludecke, T. E. (1962a): Surface Introduction of Lucerne and Cocksfoot in Central Otago. N.Z.J.A., 104: 168-175.

Lunn, W. A. (1955): Use of Lucerne for Grazing in Maniototo County. Ibid, 90:605-608.

Lynch. P. B. and Mountier, N. S. (1959): Pasture Production Estimates by Measures Other Than Cutting. Proc. 21st Conf. N.Z. Grassl. Assn.: 99-107.

McCraw, J. D. (1957): Weakly Weathering, Podzolised Y.B.E.'s. N.Z. Soil News, No, 5: 167-168.

Metson, A. J. (1956): Methods of Chemical Analysis for Soil Survey Samples. N.Z. D.S.I.R. Soil Bur. Bull. No. 12.

Saunders. W. M. H. (1957): A Colorimetric Method for Total Phosphorus in Soils. N.Z. Soil News, No. 1:22-23.

Saunders. W. M. H. and Williams. E. G. (1955): Observations on the Determination of Total Organic Phosphorus in Soils. J. Soil Sci. 6: $254-267$.

Schofield, R. C. (1957): Successful Pasture Establishment in Central Otago. N.Z.J.A., 95:545. 
Taylor, N. H. and Pohlen, 1. J. (1959): A Descriptive Atlas of New Zealand. Ed. A. H. McLintock. Govt. Printer, Wellington.

Walker, T. W., Adams, A. F. R., and Orchiston,' H. D. (1955): The Effects and Interactions of Sulphur, Phosphorus, and Molybdenum on the Growth and Composition of Clovers. N.Z. J. Sci. Tech. Sec. A, $36: 470-482$

Walker, T. W., Adams, A. F. R, and Orchiston H. D. ( 1955a) : The Effects and Interactions of Molybdenum, Lime, and Phosphate Treatments on the Yield and Composition of White Clover Grown on Acid Molybdenum Responsive Soils. Plant and Soil, 6:201-220.

Walker, T. W. and Adams, A. F. R. (1958): Competition for Sulphur in a Grass Clover Association. Ibid, 9:353-366.

Walker. T. W. and Adams, A. F. R. (1958): Studies on Soil Organic Matter: I. Soil Sci., 85:307-3 18 .

Walker, T. W. and Adams, A. F. R. (1959): Studies on Soil Organic Matter: II, Ibid, 87:1 -10.

Wells, N. and Saunders, W. M. H.: Soil Studies Using Sweet Vernal to Assess Element Availability. Part 4: Phosphorus. N.Z. J. Agric. Res., $3: 279-299$.

\section{DISCUSSION}

Comment (Chairman): In Marlborough they had decreased clover growth with increased rates of sulphur but this did not occur in the presence of molybdenum.

A. When you put elemental sulphur on the soil it is mineralised to sulphate and may increase the uptake of manganese. You upset the manganese/ molybdenum balance in the clover plant and get what is known as manganese toxicity. You restore the balance by the application of molybdenum.

Comment (farmer from Central): I feel that the work of Walker, Lobb and Ludecke on mid altitude tussock has shown us there is no need for pessimism. For Is. worth of sulphurised phosphate a man can get a good deal more in f.s.d.

Q. (J. W. Woodcock): We have all been very interested in what Mr Ludecke suggests the farmers should do in Central Otago. But there the situation is uncomplicated by lime requirement, molybdenum and potash deficiency; the only two nutrient deficiencies are sulphur and phosphate and work on the 8 or 9 soil types fits like a glove. Do you foresee the same simplification and ease in working out the ratio of sulphur to super where you have molybdenum and potash deficiency and where you have a low $\mathbf{p H}$ ?

A. This is a very good question as the main purpose of the paper was to stress the significance of studying soil fertility problems according to soil suites; and by soil suites I mean sequences of soils increasing leaching and perhaps weathering. Investigations on soil fertility problems must be allied very closely with pedology. The whole point of the work by Professor Walker and myself is to show that you can answer many more questions if you follow a sequence of soils instead of merely looking at individual soils as they do in other countries. 1 feel if soil fertility problems were studied in this way in other parts of New Zealand we would be able to formulate a rational fertiliser programme.

Comment (I. L. Elliott): I think we have to congratulate Mr Ludecke for this particular point of view. 
Q. (Mr Jacques): You did not mention the likely cumulative effect of a series of applications of sulphur. Will it be an economic proposition to topdress these areas with lime to correct the acidity caused through the application of sulphur?

A. Ihave found that where we apply $50 \mathrm{lb}$ of sulphur to the acre, or up $200 \mathrm{lb}$ in trials over four seasons, it has had no effect on the $\mathrm{pH}$ of the soil. We are measuring $\mathrm{pH}$ levels after the use of sulphur and the evidence suggests that you have to apply large amounts of sulphur per acre to appreciably alter the soil $\mathrm{pH}$. McNeur at Grasslands had to apply $1,200 \mathrm{lb}$ of sulphur to drop the $\mathrm{pH}$ of Manawatu silt loam from 5.8 to 5.4. Even if I can persuade farmers to topdress in the way they should l have no fear of these light applications of sulphur affecting soil $\mathrm{pH}$ or acidity.

Comment (J. Bruce-Smith): Light applications of sulphur would be cycled through the plant and would not be sufficient to affect soil $\mathrm{pH}$.

Q. At Pukaki on some soils we get a response from clovers and not from lucerne, can you comment on this?

A. I do not know much about the feeding habits of lucerne but I understand it is a shallow feeder and gocs down for water and not for nutrients.

Comment (Prof. Walker): I don't believe that lucerne goes down just for water, it is just as likely to pick up sulphate on the way down.

A. In the analysis of the brown grey earths at Alexandra for the Soil Congress over 50 per cent of the salt in the sub soil was calcium sulphate but I don't know whether you would be likely to get an accumulation of sulphate in the soils at Pukaki. 